\title{
Effect of Intercropping on Seasonal Incidence of Maize Aphid, Rhopalosiphum maidis
}

\author{
M.K. Tali*, M.K. Mahla, G. Chhangani and B. Singh \\ Department of Entomology, Rajasthan College of Agriculture, Maharana Pratap University of \\ Agriculture and Technology, Udaipur, Rajasthan-313001, India \\ *Corresponding author
}

\section{A B S T R A C T}

\section{Keywords \\ Intercropping, Maize, Aphid, \\ Rhopalosiphum maidis, Seasonal incidence}

Article Info

Accepted:

17 July 2018

Available Online:

10 August 2018
The present investigation on Effect of intercropping on seasonal incidence of maize aphid, Rhopalosiphum maidis was carried out at Instructional farm and Department of Entomology, Rajasthan College of Agriculture, MPUAT, Udaipur. Maize variety Pratap maize-5 was sown with different intercrops viz., green gram, black gram, cowpea and soyabean in kharif, 2017. The experiment was laid out in plots size $3.0 \mathrm{~m} \times 5.0 \mathrm{~m}$ replicated four times with row to row and plant to plant spacing of $60 \mathrm{~cm}$ and $20 \mathrm{~cm}$, respectively. The population of maize aphids initiated in the first week of August and remained active throughout the growing stage and reached to its peak in the second week of September. The mean aphid population had a significant positive correlation with mean atmospheric temperature in all the intercrop treatments. The correlation coefficient values in the different maize based planting patterns were: sole maize $(r=0.76)$, maize + green gram $(r=0.73)$, maize + black gram $(r=0.66)$ and maize + soybean $(r=0.63)$ except in maize + cowpea $(\mathrm{r}=0.26)$. The aphids showed a negative correlation with mean relative humidity; while, a positive correlation with total rainfall in the sole as well as intercrop treatments.

\section{Introduction}

Maize (Zea mays L.) belongs to family Poaceae and is one of the most versatile crop having high yield potential and wide adaptability. It is used as human food, animal feed, in starch industry, corn oil production and as baby corn (Singh, 2014).

Its grain contains protein $(10 \%)$, oil (4\%), carbohydrates $(70 \%)$, fat (5 to $7 \%$ ), fiber (3 to $5 \%$ ) and minerals $(2 \%)$. Maize is cultivated on an area of 8.69 mha with a production of 21.80 million tonnes and productivity of $2509 \mathrm{~kg} / \mathrm{ha}$ (Anonymous, 2016). Rajasthan is one of the major maize growing states in India covering an area of 0.88 mha with a production of 1.14 million tonnes and productivity of $1318 \mathrm{~kg} /$ ha (Govt. of Rajasthan. 2016). Maize can be grown in both rabi and kharif seasons in Rajasthan, but it is a major kharif season crop in the maize growing districts. The area under rabi maize is increasing in Banswara and Dungarpur districts of the state where irrigation facilities are available. Among the cultural methods, inter and mixed cropping systems, the popular forms of crop-crop diversity, have become 
more popular in the rainfed regions. Intercropping is one of the important cultural practices for pest management, which is based on the principle of reducing insect pests by increasing the diversity of an ecosystem (Letourneau and Altieri, 1983; Risch et al., 1983 and Baliddawa, 1985). Intercropping can affect the microclimate of the agro ecosystem and ultimately produce an unfavorable environment for pests.

\section{Materials and Methods}

The experiment to record the seasonal incidence of aphids was conducted in plots size of $3.0 \mathrm{~m} \times 5.0 \mathrm{~m}$ replicated four times with row to row and plant to plant spacing of $60 \mathrm{~cm}$ and $20 \mathrm{~cm}$, respectively. The insect pest complex infesting the maize crop was recorded from 21 days after germination till harvest of crop at weekly interval. The population of aphids in maize ecosystem was recorded and data obtained were using suitable statistical tools.

\section{Sampling techniques}

Five randomly selected plants were tagged and observations were recorded from $15 \mathrm{~cm}$ tassel and three leaves (top, middle and lower) of each selected plant by visual count during morning hours (7.30 - 9.00 AM) depending upon their occurrence in field during crop season at weekly intervals. The numbers aphids were correlated with prevailing meteorological parameters using suitable statistical tools.

\section{Statistical analysis}

The abiotic factors viz., temperature, relative humidity and rainfall were recorded throughout the crop season and simple correlation with the population of aphids was workout using the method suggested by Karl Pearson.

$$
r_{x y}=\frac{\sum X Y-\frac{\sum X \sum Y}{n}}{\sqrt{\left[\sum X^{2}-\frac{\left(\sum X\right)^{2}}{n}\right]\left[\sum Y^{2}-\frac{\left(\sum Y\right)^{2}}{n}\right]}}
$$

Where,

$r_{x y}=$ Simple correlation coefficient

$\mathrm{X}=$ Variable i.e. abiotic component.

(Average temperature, relative humidity and total rainfall)

$\mathrm{Y}=$ Variable i.e. mean number of aphid and their associated natural enemies per plant.

$\mathrm{n}=$ Number of observations.

The correlation coefficient (r) values will be subjected to the test of significance using ttest:

$$
\mathrm{t}=\frac{\mathrm{r}}{\sqrt{1-\mathrm{r}^{2}}} \times \sqrt{\mathrm{n}-2} \sim \mathrm{t}_{\mathrm{n}-2} \text { d.f. }
$$

The calculated t-value obtained will be compared with tabulated t-value at $1 \%$ and $5 \%$ level of significance.

\section{Results and Discussion}

The seasonal incidence of the aphids infesting maize has been presented in Table 1. During the crop season, aphids infestation began from the first week of August, 2017 that gradually increased and reached to a peak in the second week of September, 2017 with a mean of 40.00, 25.00, 26.00, 20.60 and 38.60 aphids per plant in maize sole, maize + green gram, maize + black gram, maize + cowpea and maize + soybean, respectively. 
Table.1 Seasonal population of aphids on maize cultivated sole and with intercrops during kharif, 2017

\begin{tabular}{|c|c|c|c|c|c|c|c|c|}
\hline \multirow{2}{*}{$\begin{array}{c}\text { Dates of } \\
\text { observation }\end{array}$} & \multirow{2}{*}{$\begin{array}{l}\text { Mean Atm. } \\
\text { Temp. }\left({ }^{\circ} \mathrm{C}\right)\end{array}$} & \multirow{2}{*}{$\begin{array}{l}\text { Mean RH. } \\
(\%)\end{array}$} & \multirow{2}{*}{$\begin{array}{c}\text { Total } \\
\text { Rainfall } \\
(\mathrm{mm})\end{array}$} & \multicolumn{5}{|c|}{ Mean No. of aphids/plant on maize based planting patterns } \\
\hline & & & & M & $\mathbf{M}+\mathbf{G g}$ & $\mathbf{M}+\mathbf{B g}$ & $\mathbf{M}+\mathbf{C}$ & $\mathbf{M}+\mathbf{S}$ \\
\hline $07-$ Aug & 25.70 & 87.80 & 0.00 & 5.40 & 1.20 & 0.80 & 0.00 & 1.60 \\
\hline $14-$ Aug & 26.40 & 85.40 & 2.80 & 19.00 & 8.20 & 8.00 & 5.00 & 6.00 \\
\hline $21-$ Aug & 27.00 & 69.80 & 4.20 & 32.00 & 20.00 & 20.00 & 2.40 & 25.00 \\
\hline 28-Aug & 27.40 & 82.10 & 107.20 & 38.00 & 24.20 & 25.00 & 6.00 & 29.80 \\
\hline 04-Sept & 25.40 & 85.70 & 71.80 & 10.00 & 1.20 & 0.40 & 5.60 & 0.60 \\
\hline $11-$ Sept & 26.10 & 73.90 & 0.00 & 40.00 & 25.00 & 26.00 & 20.60 & 38.60 \\
\hline 18 - Sept & 26.20 & 83.90 & 38.60 & 10.00 & 6.00 & 1.40 & 8.60 & 15.00 \\
\hline 25-Sept & 26.60 & 62.60 & 0.00 & 35.60 & 13.40 & 15.00 & $5 . .40$ & 20.00 \\
\hline $02-$ Oct & 27.00 & 54.30 & 0.00 & 30.00 & 15.00 & 10.40 & 4.60 & 18.40 \\
\hline 09- Oct & 26.60 & 43.80 & 0.00 & 22.00 & 10.00 & 8.00 & 1.20 & 13.60 \\
\hline 16-Oct & 25.00 & 45.00 & 0.00 & 5.00 & 3.20 & 2.20 & 0.80 & 3.40 \\
\hline $\begin{array}{l}\text { Seasonal } \\
\text { Mean }\end{array}$ & 26.31 & 70.39 & 20.42 & 22.45 & 11.58 & 10.65 & 4.98 & 15.64 \\
\hline \multicolumn{4}{|c|}{$\begin{array}{l}\text { Coefficient of correlation (r) b/w aphids and mean Atm. } \\
\text { Temp. }\end{array}$} & $0.765 *$ & $0.731 *$ & $0.664 *$ & 0.268 & $0.639 *$ \\
\hline \multicolumn{4}{|c|}{ Coefficient of correlation (r) b/w aphids and mean RH } & -0.107 & -0.062 & -0.014 & 0.083 & -0.049 \\
\hline \multicolumn{4}{|c|}{ Coefficient of correlation (r) b/w aphids and Total Rainfall } & 0.065 & 0.130 & 0.135 & 0.526 & 0.094 \\
\hline
\end{tabular}

* Significant at $5 \%$ level of significance

Legend: $\mathrm{M}=$ Maize sole, $\mathrm{M}+\mathrm{Gg}=$ Maize + Geengram (1:1), $\mathrm{M}+\mathrm{Bg}=$ Maize + Blackgram (1:1), $\mathrm{M}+\mathrm{C}=$ Maize + Cowpea $(1: 1), \mathrm{M}+\mathrm{S}=\mathrm{Maize}+\mathrm{Soybean}$ $(1: 1)$ 
Table.2 Effect of intercropping on the population of aphids in maize during Kharif, 2017

\begin{tabular}{|l|c|}
\hline \multicolumn{1}{|c|}{ Treatments } & Aphids (Mean/plant) \\
\hline Maize sole & 5.50 \\
\hline Maize + Greengram & 2.50 \\
\hline Maize + Blackgram & 3.75 \\
\hline Maize + Cowpea & 1.75 \\
\hline Maize + Soybean & 4.75 \\
\hline S. Em. \pm & $\mathbf{0 . 7 9}$ \\
\hline C. D. at 5\% & $\mathbf{2 . 4 2}$ \\
\hline
\end{tabular}

\section{Treatments details}

\begin{tabular}{|c|}
\hline S. No \\
\hline $\mathbf{T}_{1}$ \\
\hline $\mathbf{T}_{2}$ \\
\hline $\mathbf{T}_{3}$ \\
\hline $\mathbf{T}_{4}$ \\
\hline $\mathbf{T}_{5}$ \\
\hline
\end{tabular}

\begin{tabular}{|c|}
\hline Treatment \\
\hline Maize sole \\
\hline Maize +Greengram $(1: 1)$ \\
\hline Maize +Blackgram $(1: 1)$ \\
\hline Maize +Cowpea $(1: 1)$ \\
\hline Maize +Soybean $(1: 1)$ \\
\hline
\end{tabular}

On the basis of seasonal mean, the lowest population was recorded on maize + cowpea (4.98 aphids/ plant), followed by that on maize + black gram (10.65 aphids/ plant) while, maximum population (22.45 aphids/ plant) was recorded on sole maize.

The aphid population data when analyzed showed that significantly lowest mean population of aphids per plant was recorded under intercrop treatments as compared to sole maize. When maize was intercropped with legumes the minimum mean aphid population per plant was recorded in maize + cowpea (1.75), followed by that in maize + green gram (2.50), maize + black gram (3.75) and maize + soybean (4.75); while, maximum mean aphid population was recorded in sole maize (5.50). Among the intercrops, maize + cowpea (1:1) significantly suppressed the aphid population on maize as compared to maize sole (Table 2).

The mean aphid population had a significant positive correlation with mean atmospheric temperature in all the intercrop treatments. The correlation coefficient values in the different maize based planting patterns were: sole maize $(\mathrm{r}=0.76)$, maize + green gram $(\mathrm{r}=0.73)$, maize + black gram $(\mathrm{r}=0.66)$ and maize + soybean $(\mathrm{r}=0.63)$ except in maize + cowpea $(\mathrm{r}=0.26)$.

The aphids showed a negative correlation with mean relative humidity and while a positive correlation with total rainfall in the sole as well as intercrop treatments.

The present findings are in accordance with that of Carena and Glogoza (2004) and Razmjou and Golizadeh, (2010), who reported that the corn leaf aphid, Rhopalosiphum maidis (Fitch) is one of the important pests of maize with worldwide distribution.

Aphids occurred at the beginning of August, and reached their maximum abundance (406 and 518 per plant) in the 4th week of August, when the plants were in their reproductive stage. Aphid populations began to decrease from the 3rd week of September, to reach their lowest levels in mid-October, when the plants were mature (Darwish and Ali, 2001). Rana (1998) reported that the activity of $R$. maidis 
started when maximum temperature and minimum temperature ranged between 25.6 to $27.2^{\circ} \mathrm{C}$ and 6.9 to $8.2^{\circ} \mathrm{C}$, respectively. According to Chansigaud and Vaillant (1987) population fluctuations and distribution of aphids ( $R$. maidis) on maize was recorded in July which remained until late October.

One potential benefit associated with intercropping that has received increased attention over recent years has been its use as a strategy for crop protection against insect pests (Ponti et al., 2007; Fiedler et al., 2008; Khan et al., 2008).

\section{Acknowledgment}

The authors sincerely thank the Head, Department of Entomology, Dean, Rajasthan College of Agriculture and Director Research, MPUAT, Udaipur for providing the necessary facilities to conduct the research.

\section{References}

Anonymous, 2016. Directorate of economics and statistics, Department of Agriculture and Cooperation, Ministry of Agriculture, Goverment of India.

Anonymous, 2016. Vital Agriculture Statistics, Statistics Cell, Directorate of Agriculture, Pant Krishi Bhawan, Jaipur. Govt. of Rajasthan p.47.

Baliddawa, C.W. 1985. Plant species diversity and crop pest control - an analytical review. Insect Sci. App., 6: 479-487.

Carena, M.J. and Glogoza, P. 2004. Resistance of corn to the corn leaf aphid: a review. Maydica, 49: 241-254.

Chansigaud, J. and Vaillant, J. 1987. Bulletin SROP. 10 (1): 23.
Darwish, Y.A. and Ali, A.M. 2001. Field population trends of cereal aphids and their natural enemies on corn plants in Upper Egypt. Assiut J. Agri. Sci. 22:33-42.

Fiedler, A.K., Landis, D.A. and Wratten, S.D. 2008. Maximizing ecosystem services from conservation biological control: The role of habitat management. Bio. Cont., 45: 254271.

Khan, Z.R., James, D.G., Midega, C.A.O. and Pickett, J.A. 2008. Chemical ecology and conservation biological control. Bio. Cont., 1: $1-15$.

Letourneau, D.K and Altieri, M.A. 1983. Abundance patterns of a predator, Orius tristicolor (Hemiptera: Anthocoridae) and its prey, Frankliniella occidentalis (Thysanoptera: Thripidae): habitat attraction in polycultures versus monocultures. Environ. Ento., 12: 14641469.

Ponti, L., Altieri, M. A. and Gutierrez, A. P. 2007. Effects of crop diversification levels and fertilization regimes on abundance of Brevicoryne brassicae (L.) and its parasitization by Diaeretiella rapae in broccoli. Agri. Forest Ento., 9: 209-214.

Rana, B.S. 1998. Investigation on the feeding and reproductive potential of Chrysoperla carnea Stephen and its utilization as an IPM component in the management of aphids infesting barley, cowpea and mustard. Thesis submitted, RAU, Bikaner.

Razmjou, J. and Golizadeh, A. 2010. Performance of corn leaf Aphid, Rhopalosiphum maidis (Fitch) (Homoptera: Aphididae) on selected maize hybrids under laboratory conditions. Appl. Ento. Zoo. 45: 267-274.

Risch, S.J., Andow, D. and Altieri M.A. 1983. Agro-ecosystem diversity and pest control: data, tentative conclusions, and new direction. Environ. Ento., 12: 625-629.

Singh, A.D. 2014. Maize in India. India Maize Summit. FICCI, pp 2.

\section{How to cite this article:}

Tali, M.K., M.K. Mahla, G. Chhangani and Singh, B. 2018. Effect of Intercropping on Seasonal Incidence of Maize Aphid, Rhopalosiphum maidis. Int.J.Curr.Microbiol.App.Sci. 7(08): 2984-2988. doi: https://doi.org/10.20546/ijcmas.2018.708.316 